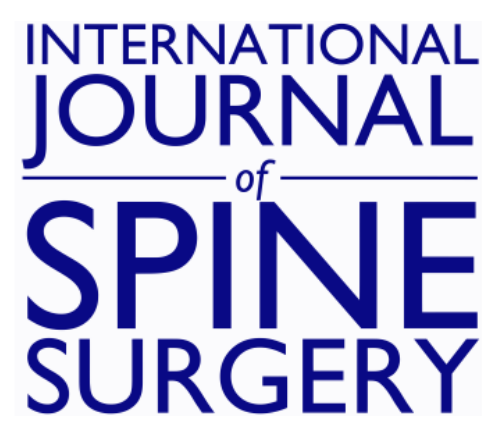

\title{
Cervical Myelopathy Secondary to Combined Ossification of Ligamentum Flavum and Posterior Longitudinal Ligament-- A Case Report
}

\author{
SOURABH CHACHAN, NIRAJ SHARAD KASAT and PAUL THNG LEONG KENG
}

Int J Spine Surg 2018, 12 (2) 121-125

doi: https://doi.org/10.14444/5018

http://ijssurgery.com/content/12/2/121

This information is current as of April 26, 2023.

Email Alerts Receive free email-alerts when new articles cite this article. Sign up at:

http://ijssurgery.com/alerts

The International Journal of Spine Surgery

2397 Waterbury Circle, Suite 1,

Aurora, IL 60504, Phone: +1-630-375-1432 


\title{
Cervical Myelopathy Secondary to Combined Ossification of Ligamentum Flavum and Posterior Longitudinal Ligament-A Case Report
}

\author{
SOURABH CHACHAN, MBBS, MS, MRCS, NIRAJ SHARAD KASAT, MBBS, MS, PAUL THNG LEONG \\ KENG, MBBS FRCS(ED), FRCS(G) \\ Department of Orthopaedics, Changi General Hospital, Singapore
}

\begin{abstract}
In the cervical spine, the combined ossification of the ligamentum flavum (OLF) and posterior longitudinal ligament is rarely seen. Patients are usually treated with cervical laminectomy or laminoplasty with OLF resection. In most of the cases, OLF is adhered to the dura and there is a risk of dural tear or cerebrospinal fluid (CSF) leakage during its resection. In this case report, the authors present results of laminectomy with debulking instead of complete excision of OLF for spinal cord decompression in a cervical myelopathy case in which OLF was adhered to the dura. A 69-year-old man presented with insidious onset weakness in bilateral lower limbs and unsteady gait, which he had experienced 1 month. He has a history of neck pain with left upper limb radiation for the last 2 years. Magnetic resonance imaging showed C5-6 severe central canal stenosis with underlying myelomalacia. Computed tomography showed ossification posterior longitudinal ligament and OLF contributing to severe central canal stenosis at the C5-6 level. The patient underwent C4C6 laminectomy, debulking of OLF, posterior instrumentation, and fusion with autogenous bone graft from C3 to C6. A histological specimen showed osseous tissue within the ligamentum flavum. After surgery the patient's symptoms improved and no recurrence was observed at 4 years after surgery. The symptoms of myelopathy were successfully treated with debulking instead of complete excision of OLF, thus reducing the risk of dural tear or CSF leakage.
\end{abstract}

Cervical Spine

Keywords: ossification of ligamentum flavum (OLF), ossification of posterior longitudinal ligament (OPLL), cervical myelopathy, dural tear

\section{INTRODUCTION}

In the cervical spine, the combination of ossified ligamentum flavum (OLF) and ossified posterior longitudinal ligament (OPLL) has rarely been seen. ${ }^{1-7}$ We describe a case of cervical myelopathy secondary to OPLL and OLF that required surgery. Usually, the patients are treated with cervical laminectomy or laminoplasty and OLF resection. ${ }^{8-11}$ In most cases, OLF is adhered to the dura and there is a risk of dural tear or cerebrospinal fluid (CSF) leakage during its resection. ${ }^{9,12} \mathrm{We}$ describe the result of laminectomy and debulking instead of complete excision of OLF to decompress the cervical cord, followed by fusion, thus reducing the risk of dural tear or CSF leakage.

\section{CASE DESCRIPTION}

A 69-year-old Chinese man presented with insidious onset motor weakness and numbness in bilateral lower limbs. He complained of frequent loss of balance due to unsteady gait for 1 month. He had a history of neck pain radiating to the left upper limb for the last 2 years. On examination, motor weakness was noted mainly in the left upper limb and lower limb (4/5), deep tendon reflexes were elevated at and below the biceps, Babinski's sign was positive, and the Hoffman sign was present. Sensory tests showed hypaesthesia below the level of C6. Tandem gait test was positive. Bowel and bladder functions were normal. The Japanese Orthopaedic Association Cervical Myelopathy Score (JOA) was 7/17.

A cervical spine X-ray showed mild straightening of cervical spine on neutral images. Magnetic resonance imaging showed disc osteophyte complexes at C3-4 (indenting the thecal sac) and C4-5 (indenting the anterior contour of the spinal cord) and severe central canal stenosis at the C5-6 level on $\mathrm{T} 1$ and T2 weighted images (Figure 1). The cervical 


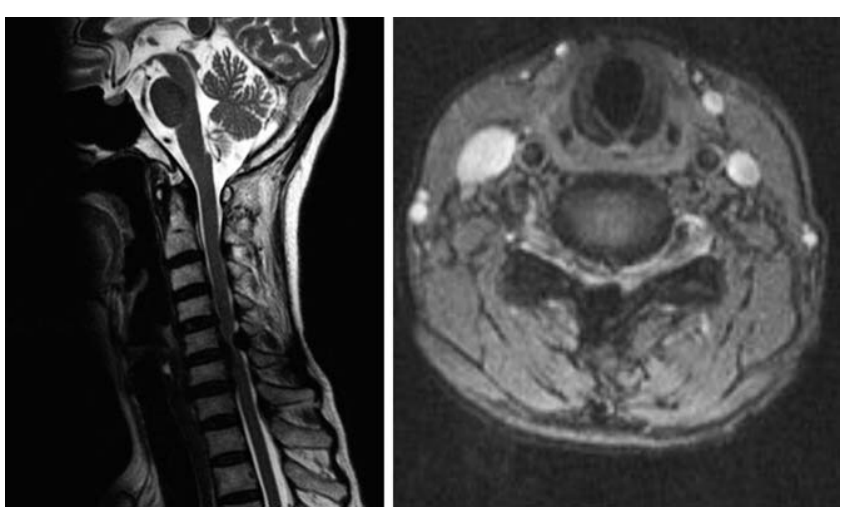

Figure 1. Magnetic resonance image showing disc osteophyte complexes and central canal stenosis from C3-C6.

cord at this level revealed high T2 signals consistent with myelomalacia. Computed tomography (CT) showed segmental OPLL and OLF from C4-C6 contributing to severe central canal stenosis at the C5-6 level (Figure 2).

\section{SURGICAL TECHNIQUE}

Standard dorsal midline cervical spine approach was used. Intraoperative spinal cord monitoring was used throughout the procedure. Lateral mass screws were inserted at the C3 to C6 levels using a modified Magerl technique. The final construct was completed using rods (Figure 3 ). The spinous processes from C3 to $\mathrm{C} 6$ were excised. Laminectomy was performed at the C4-C6 level using Midas AM8 burr. Macroscopically, an ossified mass, measuring approximately $1.5 \mathrm{~cm}$ by $1.5 \mathrm{~cm}$ by $1 \mathrm{~cm}$, was noted at the C5-6 level (Figure 4). Adherence was noted between the ossified mass and the underlying dura. Using a sharp nerve hook, a plane was defined between the ligamentum flavum and dura away from the ossified mass. Spinal cord was decompressed circumferentially by debulking the ossified mass from the periphery (Figure 5). After debulking, the cord was noted to be pulsating with remnant ossified mass floating over the dura. The surgical wound was closed in a meticulous manner.

\section{RESULTS}

Histological examination showed fibrocartilage with large areas of degenerative calcification within the excised surgical specimen, which confirmed the diagnosis of OLF. After surgery, the patient's symptoms improved significantly. His gait was steady and he was able to walk independently. At 6 months postoperatively, his JOA score improved to $11 / 17$. At 4 years postoperatively, he was walking independently with full power in upper and lower limbs, and his JOA score was 15/17.

\section{DISCUSSION}

Ossified ligamentum flavum has been considered a disease of mostly the Japanese and East Asian populations, with sporadic reports in other communities. ${ }^{13-18}$ The relative incidence of OLF in the thoracic, lumbar, and cervical spine is approximately $38.5 \%, 26.5 \%$, and $0.9 \%$, respectively. ${ }^{19-22}$ In the entire cervical spine, 50 cases have been reported to date. $^{23-29}$ In the high cervical region (C1-C4), however, its occurrence is extremely rare. ${ }^{23,25,29}$ The combination of OPLL and OLF is even rarer, with only 6 reported cases of combined OPLL and OLF in the literature..$^{1}$ In three of the six cases, OLF was located at the OPLL margin, and in the other three cases, the OLF was located at the segment close to the end of the OPLL. ${ }^{1}$ In our case,
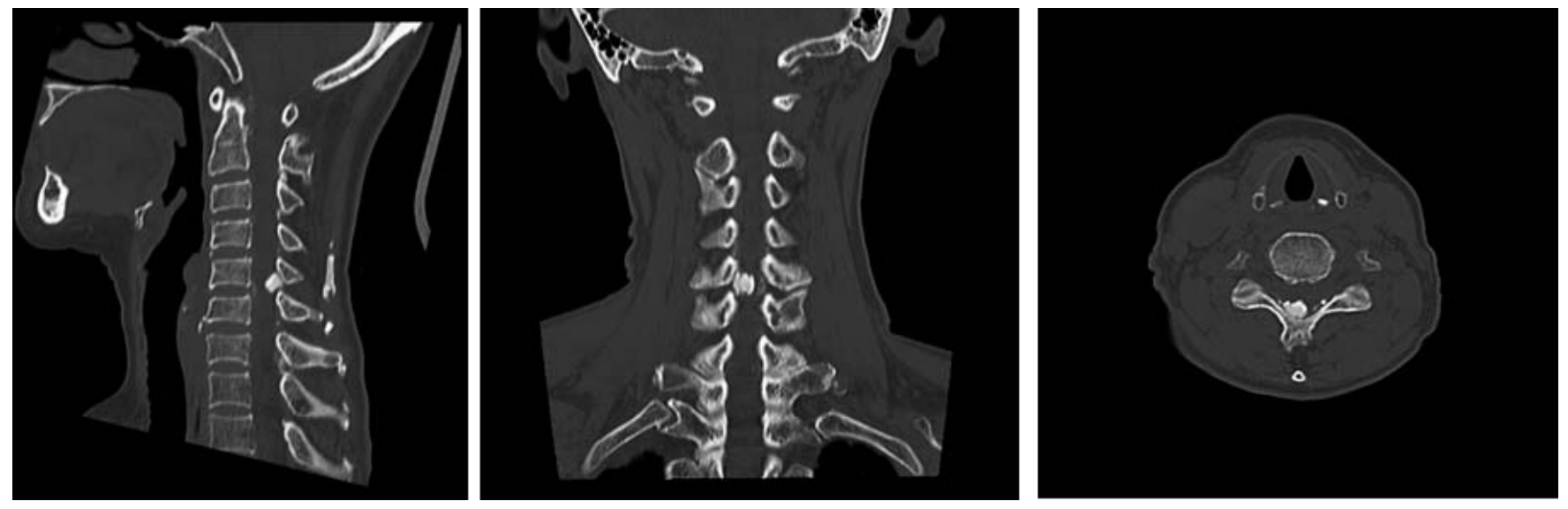

Figure 2. Computed tomography images showing segmental ossified posterior longitudinal ligament and ossified ligamentum flavum from C4-C6 contributing to severe central canal stenosis at the C5-6 level. 

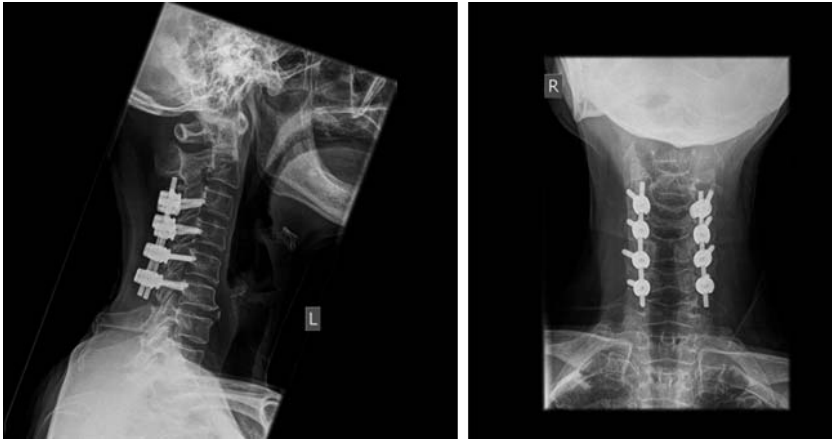

Figure 3. Postoperative X-rays antero-posterior and lateral views.

segmental OPLL was seen at C4-C6, and OLF was seen at C5-C6, mainly in the center and on the left side. There was no concomitant ossification of general ligaments or other spinal ligaments. Based on the literature review, cervical OLF tends to occur adjacent or close to the cervical OPLL margin, suggesting that the increased mechanical stress at the OPLL junction may be a causative factor. ${ }^{1}$ Histological examination of the surgical specimen in our case showed osseous tissue, confirming the

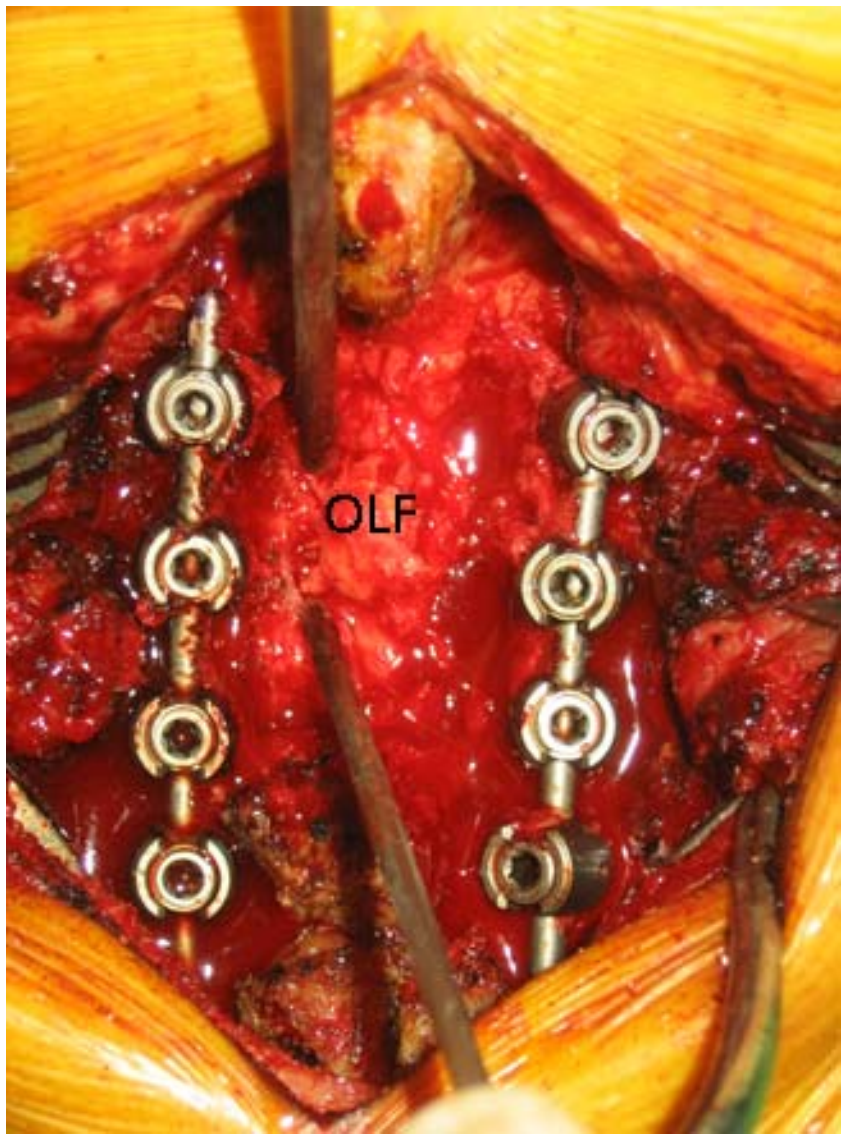

Figure 4. Intraoperative image showing ossified ligamentum flavum at the C56 level. Abbreviation: OLF, ossified ligamentum flavum. diagnosis as in other cases reported in the literature. ${ }^{1,8}$ Both extrinsic and intrinsic factors have been proposed in the aetiology of OLF. ${ }^{12}$ Serum levels of fibronectin and bone morphogenetic protein thought to be responsible for proliferation of fibroblasts in Japanese patients were not determined in our patient. ${ }^{12}$

With the purpose of helping surgical decision making, Sato et al classified thoracic OLF into 5 types: lateral, extended, enlarged, fused, and tuberous. ${ }^{30}$ However, the authors did not use that classification system in the current case, as the usefulness of the Sato et al classification has not been validated in the cervical spine; furthermore the surgical technique used by the authors was not proposed in the original paper by Sato et al. ${ }^{30}$

The treatment options for OFL described in the literature are laminoplasty/laminotomy with enblock resection and rare mention of laminectomy with floating ossified dura. ${ }^{12}$ Among these, decompressive laminectomy or laminoplasty and excision of the OLF are the commonly performed surgical procedures. ${ }^{8,31}$ Limited surgery including foraminotomy or extended partial laminectomy is also described in literature. ${ }^{10}$ The surgical technique of drilling and yellow ligament excision, as described by Mohindra et al, ${ }^{11}$ requires precision and is technically demanding. Yang et $\mathrm{al}^{8}$ noted cervical ossified ligamentum flavum to be adhered to the dura in $67.7 \%$ of all his cases. Ossified ligamentum flavum is adhered to the dura, and complete excision brings significant risk of dural tear, CSF leakage, spinal cord injury, or spinal cord herniation. . $^{8,9,11}$ Postoperative neurological deterioration is the most

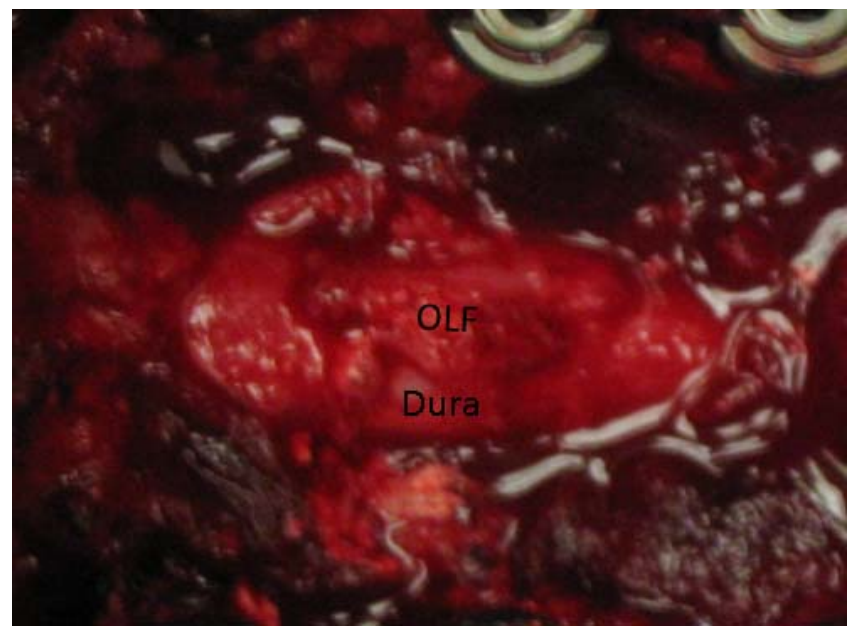

Figure 5. Intraoperative image after peripheral debulking of ossified ligamentum flavum (OLF). 
serious and unexpected complication with complete surgical resection of OLF. In our case we excised the laterally extending OLF circumferentially, leaving the central mass. At the end of decompression, the left-over central mass was floating over the bulgedout dura. The spinal cord was noted to be pulsating freely. There was no need to excise the ossified mass completely, as the spinal cord was decompressed adequately. In the opinion of the senior author, it is easy to find the plane between the ossified mass and ligamentum flavum at the periphery, making circumferential decompression safe. It also allows far lateral decompression of the nerve roots and radicular arteries. The central ossified mass is firmly adhered and hence difficult to dissect from the dura. With circumferential excision of laterally extending OLF, the spinal cord is adequately decompressed, making complete excision unnecessary. The literature suggests increased incidence of postlaminectomy cervical kyphosis in cases of multilevel laminectomy. ${ }^{32}$ Furthermore, preoperative evidence of loss of cervical lordosis acts as a predisposing factor. ${ }^{32}$ In the current case with multilevel laminectomies and preoperative evidence of straightening of cervical spine, the decision was made to fuse prophylactically to avoid postlaminectomy kyphosis.

\section{CLINICAL SIGNIFICANCE}

The authors think that debulking instead of complete excision of OLF may be effective and safer for spinal cord decompression in cases of cervical myelopathy secondary to combined ossification of OPLL and OLF.

\section{REFERENCES}

1. Kotani Y, Takahata M, Abumi K, Ito M, Sudo H, Minami A. Cervical myelopathy resulting from combined ossification of the ligamentum flavum and posterior longitudinal ligament: report of two cases and literature review. Spine $J$. 2013;13(1):1-6.

2. Inoue $\mathrm{H}$, Seichi $\mathrm{A}$, Kimura $\mathrm{A}$, Endo $\mathrm{T}$, Hoshino $\mathrm{Y}$. Multiple-level ossification of the ligamentum flavum in the cervical spine combined with calcification of the cervical ligamentum flavum and posterior atlanto-axial membrane. Eur Spine J. 2013;22(Suppl 3):S416-S420.

3. Guo Q, Ni B, Yang J, Zhu Z, Yang J. Simultaneous ossification of the posterior longitudinal ligament and ossification of the ligamentum flavum causing upper thoracic myelopathy in DISH: case report and literature review. Eur Spine J. 2011;20(suppl 2):S195-S201.

4. Pascal-Moussellard H, Cabre P, Smadja D, Kaidomar S, Catonne Y. Myelopathy due to calcification of the cervical ligamenta flava: a report of two cases in West Indian patients. Eur Spine J. 1999;8(3):238-240.

5. Takayama S, Kuribayashi K, Miyamoto Y, Nakasu Y, Handa J. Ossification and calcification of the cervical ligamentum flavum - case reports. No To Shinkei. 1993;45(9):859-863.

6. Hukuda S, Mochizuki T, Ogata M, Shichikawa K. The pattern of spinal and extraspinal hyperostosis in patients with ossification of the posterior longitudinal ligament and the ligamentum flavum causing myelopathy. Skeletal Radiol. 1983;10(2):79-85

7. Park JY, Chin DK, Kim KS, Cho YE. Thoracic ligament ossification in patients with cervical ossification of the posterior longitudinal ligament: tandem ossification in cervical and thoracic spine. Spine (Phila Pa 1976). 2008;33(13):407-410.

8. Yang J, Ni B, Xie N, Guo Q, Wang L. Surgical treatments of myelopathy caused by cervical ligamentum flavum ossification. World Neurosurg. 2011;75(3-4):546-550.

9. Ohnishi $\mathrm{Y}$, Iwatsuki $\mathrm{K}$, Yoshimura $\mathrm{K}$, Ishihara $\mathrm{M}$, Yoshimine T. Incarcerated herniation of the cervical spinal cord after laminectomy for an ossification of the yellow ligament. Eur Spine J. 2010;19(2):140-143.

10. Ido K, Shimizu K, Iida H, Nakamura T. Surgical treatment for ossification of the posterior longitudinal ligament and the yellow ligament in the thoracic and cervico-thoracic spine. Spinal Cord. 1998;36(8):561-566.

11. Mohindra S, Gupta R, Chhabra R, Gupta SK. Compressive myelopathy due to ossified yellow ligament among South Asians: analysis of surgical outcome. Acta Neurochir (Wien). 2011;153(3):581-587.

12. Ahn DK, Lee S, Moon SH, Boo KH, Chang BK, Lee JI. Ossification of the ligamentum flavum. Asian Spine $J$. 2014;8(1):89-96.

13. Miyasaka K, Kaneda K, Sato S, et al. Myelopathy due to ossification or calcification of the ligamentum flavum: radiologic and histologic evaluations. AJNR Am J Neuroradiol. 1983;4(3):629-632.

14. Guo JJ, Luk KD, Karppinen J, Yang H, Cheung KM. Prevalence, distribution, and morphology of ossification of the ligamentum flavum: a population study of one thousand seven hundred thirty-six magnetic resonance imaging scans. Spine (Phila Pa 1976). 2010;35(1):51-56.

15. Hanakita J, Suwa H, Nagayasu S, Nishi S, Ohta F, Sakaida H. Clinical analysis of ossified thoracic ligaments and thoracic disc hernia. Neurol Med Chir (Tokyo). 1991;31(13):936-942.

16. Arafat QW, Jackowski A, Chavda SV, West RJ. Case report: ossification of the thoracic ligamenta flava in a Caucasian: a rare cause of myelopathy. $\mathrm{Br} J$ Radiol. 1993;66(792):1193-1196.

17. Coulier B, Ghosez JP, Mailleux P. Computed tomography diagnosis of symptomatic ossification of the thoracic flaval ligaments. JBR-BTR. 1998;81(3):137-140.

18. Tokala DP, Lam KS, Prince HG. Ossification of the proximal thoracic ligamenta flava causing acute myelopathy in a Caucasian: case report and literature review. Spinal Cord. 2007;45(4):310-313.

19. Chou YC, Lee CC, Yen PS, et al. Cough induced by ossification of the ligamentum flavum in the high cervical spine: case report. J Neurosurg. 2004;100(suppl 4):364-366.

20. Fujiwara M, Bitoh S, Hasegawa H, Nakata M, Hata H. 
A case of nodular calcification of the ligamentum flavum with ossification of the posterior longitudinal ligament in the cervical spine. No Shinkei Geka. 1982;10(7):769-774.

21. Hirabayashi H, Ebara S, Takahashi J, et al. Surgery for thoracic myelopathy caused by ossification of the ligamentum flavum. Surg Neurol. 2008;69(2):114-116.

22. Kobayashi S, Okada K, Onoda K, Horikoshi S. Ossification of the cervical ligamentum flavum. Surg Neurol. 1991;35(3):234-238.

23. Minamide A, Yoshida M, Kawakami M. Factors affecting clinical outcomes following spinal decompression surgery for ossification of ligamentum flavum in the thoracic spine. Spine J. 2007;7(5 suppl):73S.

24. Miyazawa N, Akiyama I. Ossification of the ligamentum flavum of the cervical spine. J Neurosurg Sci. 2007;51(3):139-144.

25. Mizuno J, Nakagawa $H$. Unilateral ossification of the ligamentum flavum in the cervical spine with atypical radiological appearance. J Clin Neurosci. 2002;9(4):462-464.

26. Dhammi IK, Jain AK, Arora A. Thoracic myelopathy secondary to ossified ligamentum flavum. Report of two cases. Ind J Orthopaedics. 2002;36(3):199-202.

27. Nadkarni TD, Menon RK, Desai KI, Goel A. Ossified ligamentum flavum of the atlantoaxial region. J Clin Neurosci. 2005;12(4):486-489.

28. Nowinski GP, Visarius H, Nolte LP, Herkowitz HN. A biomechanical comparison of cervical laminoplasty and cervical laminectomy with progressive facetectomy. Spine (Phila $\mathrm{Pa}$ 1976). 1993;18(14):1995-1997.

29. Okada K, Oka S, Tohge K, Ono K, Yonenobu K, Hosoya T. Thoracic myelopathy caused by ossification of the ligamentum flavum. Spine (Phila Pa 1976). 1991;16(3):280-287.

30. Sato T, Tanaka Y, Aizawa T, Koizumi Y, Kokubun S. Surgical treatment for ossification of ligamentum flavum in the thoracic spine and its complications. Spine Spinal Cord. 1998;11(00):505-510.

31. Li F, Chen Q, Xu K. Surgical treatment of 40 patients with thoracic ossification of the ligamentum flavum. $J$ Neurosurg Spine. 2006;4(3):191-197.

32. Cho WS, Chung CK, Jahng TA, Kim HJ. Postlaminectomy kyphosis in patients with cervical ossification of the posterior longitudinal ligament: does it cause neurological deterioration? J Korean Neurosurg Soc. 2008;43(6):259-264.

Disclosures and COI: The manuscript submitted does not contain information about medical device(s)/drug(s). No benefits in any form have been or will be received from a commercial party related directly or indirectly to the subject of this manuscript.

Corresponding Author: Sourabh Chachan, MBBS, MS, MRCS, Department of Orthopaedics, Changi General Hospital, Singapore-529889. Phone: +65-9690-6470; Email: drsourabhchachan@yahoo. in.

Published 3 August 2018

This manuscript is generously published free of charge by ISASS, the International Society for the Advancement of Spine Surgery. Copyright @ 2018 ISASS. To see more or order reprints or permissions, see http://ijssurgery.com. 